\title{
Untangling the effects of size, habitat and invertebrate biodiversity on parasite prevalence in the Caribbean spiny lobster
}

\author{
Charlotte E. Davies $^{1,2}$ (D) Patricia Briones-Fourzán ${ }^{1}$ (D) Enrique Lozano-Álvarez ${ }^{1}$ (D)
}

Received: 21 February 2019 / Accepted: 23 July 2019 / Published online: 3 August 2019

(c) The Author(s) 2019

\begin{abstract}
The spiny lobster Panulirus argus is an important benthic mesopredator and a major fishing resource across the Wider Caribbean region. This species is host to the pathogenic virus PaV1 and metacercariae of Cymatocarpus solearis, a digenean trematode whose first intermediate host remains unknown. Previous studies found that the probability of infection with PaV1 was higher in juvenile lobsters and in densely vegetated habitats (suggesting that marine vegetation can be an environmental reservoir for PaV1), whereas the probability of infection with C. solearis was higher for larger lobsters and in poorly vegetated habitats. To increase insight into the role of habitat and body size in the ecology of lobster diseases, the presence of both $C$. solearis and PaV1 in P. argus was investigated across three contrasting zones in Bahía de la Ascensión, Mexico $\left(19^{\circ} 35^{\prime} 27^{\prime \prime} \mathrm{N}, 87^{\circ} 38^{\prime} 06^{\prime \prime} \mathrm{W}\right)$ : reef, lagoon and shallow habitat. Additionally, habitat complexity, cover of benthic components, and macroinvertebrate biodiversity were characterized in each zone. Consistent with previous studies, probability of infection with PaV1 (both at a clinical and infective level) decreased with increasing lobster size and was highest in the seagrass-rich lagoon, supporting the idea that marine vegetation could be an environmental reservoir for PaV1. In contrast, the probability of infection with $C$. solearis increased significantly with lobster size but did not vary with zone, suggesting no relationship with benthic substrate type. However, based on results of macroinvertebrate diversity, the gastropods Cerithium litteratum and Tegula fasciata are put forward as potential candidates for the first intermediate hosts of C. solearis.
\end{abstract}

\section{Introduction}

In the changing climate, marine diseases are thought to be on the rise (Ward and Lafferty 2004; Lafferty and Hofmann 2016). Anthropogenic factors associated with climate change, pollution and invasive species have all been

Responsible Editor: M. G. Chapman.

Reviewed by Undisclosed experts.

Electronic supplementary material The online version of this article (https://doi.org/10.1007/s00227-019-3563-8) contains supplementary material, which is available to authorized users.

Charlotte E. Davies

CEDavies72@gmail.com

1 Instituto de Ciencias del Mar y Limnología, Unidad Académica de Sistemas Arrecifales, Universidad Nacional Autónoma de México, 77580 Puerto Morelos, Quintana Roo, Mexico

2 Present Address: Department of Biosciences, College of Science, Swansea University, Singleton Park, Swansea, Wales SA2 8PP, UK research targets for understanding marine disease dynamics (Harvell et al. 2002, 2004). However, ecosystem health as a whole can be encompassed by a range of categories, from anthropogenic disturbances to ecological factors such as species richness and diversity as well as disease (Lafferty and Gerber 2002; McCallum et al. 2005; Aburto-Oropeza et al. 2015).

In the Wider Caribbean region, the spiny lobster Panulirus argus is an important benthic mesopredator and a major fishing resource, with annual landings of over 27,000 tons in the past 10 years (FishStatJ 2019). This species, however, can be infected with PaV1 (Panulirus argus virus 1), the first known naturally occurring virus of a lobster, as well as a range of macroparasites, bacteria, and fungi (see Shields 2011 for review). Panulirus argus virus 1 was first discovered as the causative agent of an emergent disease affecting $P$. argus in Florida Bay, USA in 1999 by Shields and Behringer (2004). It has since been found throughout the Caribbean (Moss et al. 2013). Panulirus argus virus 1 has been mainly reported in juvenile lobsters (Behringer et al. 2006) and is highly pathogenic. Laboratory trials have shown that PaV1 is mainly transmitted through contact 
between healthy and diseased lobsters, and to a lesser extent through ingestion of diseased tissue and through water (Butler et al. 2008).

Panulirus argus has also been found to host metacercariae of the digenean trematode, Cymatocarpus solearis (Gómez del Prado et al. 2003). The cysts of the metacercariae are large, measuring $\sim 1 \mathrm{~mm}$ in diameter on average (0.6-1.5 mm, Gómez del Prado et al. 2003; Cruz-Quintana 2012). However, trematode life cycles are typically very complex involving several intermediate hosts in addition to the definitive hosts (Cribb et al. 2003). Although the first intermediate host of this parasite is unknown, it is known that $P$. argus is a second intermediate host, with the definitive host being marine turtles. Little is known about the effects of this parasite upon the physiology or behavior of P. argus (Briones-Fourzán et al. 2016).

Host-parasite interactions are typically embedded in complex communities that may alter parasite transmission (Thieltges et al. 2008; Orlofske et al. 2012), but research into reservoirs of $\mathrm{PaV} 1$ and effects upon the ecosystem as a whole has also been limited (e.g., Butler et al. 2008). However, studies have noted higher PaV1 prevalence in densely vegetated areas compared to poorly vegetated areas, suggesting that marine vegetation may be acting as an environmental reservoir for the disease (Briones-Fourzán et al. 2012; Huchin-Mian et al. 2013). Both seagrass meadows and macroalgae have been shown to attenuate flow velocity of water (e.g., Scoffin 1970; Peterson et al. 2004), therefore, it could also be hypothesized that densely vegetated areas may cause pooling of virions from infected animals. In contrast to the disease ecology of PaV1, it was found that the prevalence of the parasite $C$. solearis was higher in poorly vegetated habitats relative to densely vegetated habitats (Briones-Fourzán et al. 2016). Also, the probability of infection decreased with increasing lobster size for PaV1, but increased with increasing lobster size for $C$. solearis, and coinfection with both parasites was almost nil. Previous studies have indicated that the biodiversity of species present as well as the habitat type and complexity can contribute to disease risk (Keesing et al. 2006; Johnson and Thieltges 2010) and it is well known that vegetation and food sources may act as vectors or reservoirs for disease (Small and Pagenkopp 2011).

The current study aims to discover more about PaV1 and the little known parasite $C$. solearis upon the populations of $P$. argus in a marine protected area in the Caribbean. The roles of habitat and surrounding communities, both as possible vectors or reservoirs, are crucial in understanding the disease ecology of these parasites and also in terms of fisheries due to the extensive use of casitas (artificial shelters) in fisheries for $P$. argus in the Caribbean. Spiny lobsters within high-risk habitats that promote disease acquisition may result in altered population dynamics and further impact upon the lucrative fishery (Stewart 1984; Shields 2011).
Investigating potential relationships between disease presence and factors such as habitat complexity, components of the benthic habitat, and species richness and species diversity (i.e., community) would be beneficial to inform scientists, fishers and managers about the current and potential effects of the diseases related to spiny lobster habitat selection.

\section{Materials and methods}

\section{Study area}

Bahía de la Ascensión (centered at 19³5'27"N, $87^{\circ} 38^{\prime} 06^{\prime \prime} \mathrm{W}$ ) is a large, shallow bay (mean depth: $2.2 \mathrm{~m}$; range $<1$ to $7 \mathrm{~m}$; Medina-Gómez et al. 2014) located within the Sian Ka' an Biosphere Reserve on the Mexican Caribbean coast of Quintana Roo (Fig. 1). The bay is bordered by extensive wetlands, in particular mangrove forests, with several mangrove keys throughout the bay, most notably at its center. The bay has relatively calm water, because an interrupted coral reef that runs parallel to the mouth of the bay reduces wave surge. Large expanses of the bay are covered by extensive meadows of mixed seagrasses and macroalgae, offering a good settlement habitat for postlarvae of P. argus (Briones-Fourzán et al. 2012). The bay is characterized by strong SW-NE salinity gradients due to freshwater supply from combined runoff and sub-marine groundwater discharges in the inner bay, and strong tidal influence in the bay's central basin favored by the open seaward front (Medina-Gómez et al. 2014). The bay sustains an important local fishery for $P$. argus based on the extensive use of "casitas", artificial habitats constructed of concrete that mimic large crevice-type shelters sought by $P$. argus, widely used for lobster fishing in the Caribbean (Lozano-Álvarez et al. 1991). The only human settlement along the entire margin of the bay is a small village (Javier Rojo Gómez), which is located on the land point named Punta Allen (Fig. 1). The village is the seat of the local fishing cooperative, which holds the concession to fish for lobsters in the entire bay and adjacent marine areas.

\section{Sampling operations}

Historically, the fishing cooperative has been supportive of scientific research in the bay; however, they prefer that research activities take place during the lobster closed season (March 1 to June 30) so as not to interfere with fishing activities. Therefore, sampling took place in April-May 2017. Three bay zones were sampled with contrasting types of habitats: the interface between the reef lagoon and the back reef zone along a large reef (hereafter "Reef", centered at $19^{\circ} 47^{\prime} 29.70^{\prime \prime} \mathrm{N}, 87^{\circ} 26^{\prime} 39.18^{\prime \prime} \mathrm{W}$ ), the middle 
Fig. 1 Schematic maps showing a the approximate location of Bahía de la Ascensión in the Caribbean coast of Mexico (red square), $\mathbf{b}$ the general study area (red rectangle), and $\mathbf{c}$ the three sampling zones in the bay: Reef (blue), Lagoon (green), and Shallow (orange). The black patches denote the location of the coral reef crest and the yellow dot denotes the location of the only village around the bay
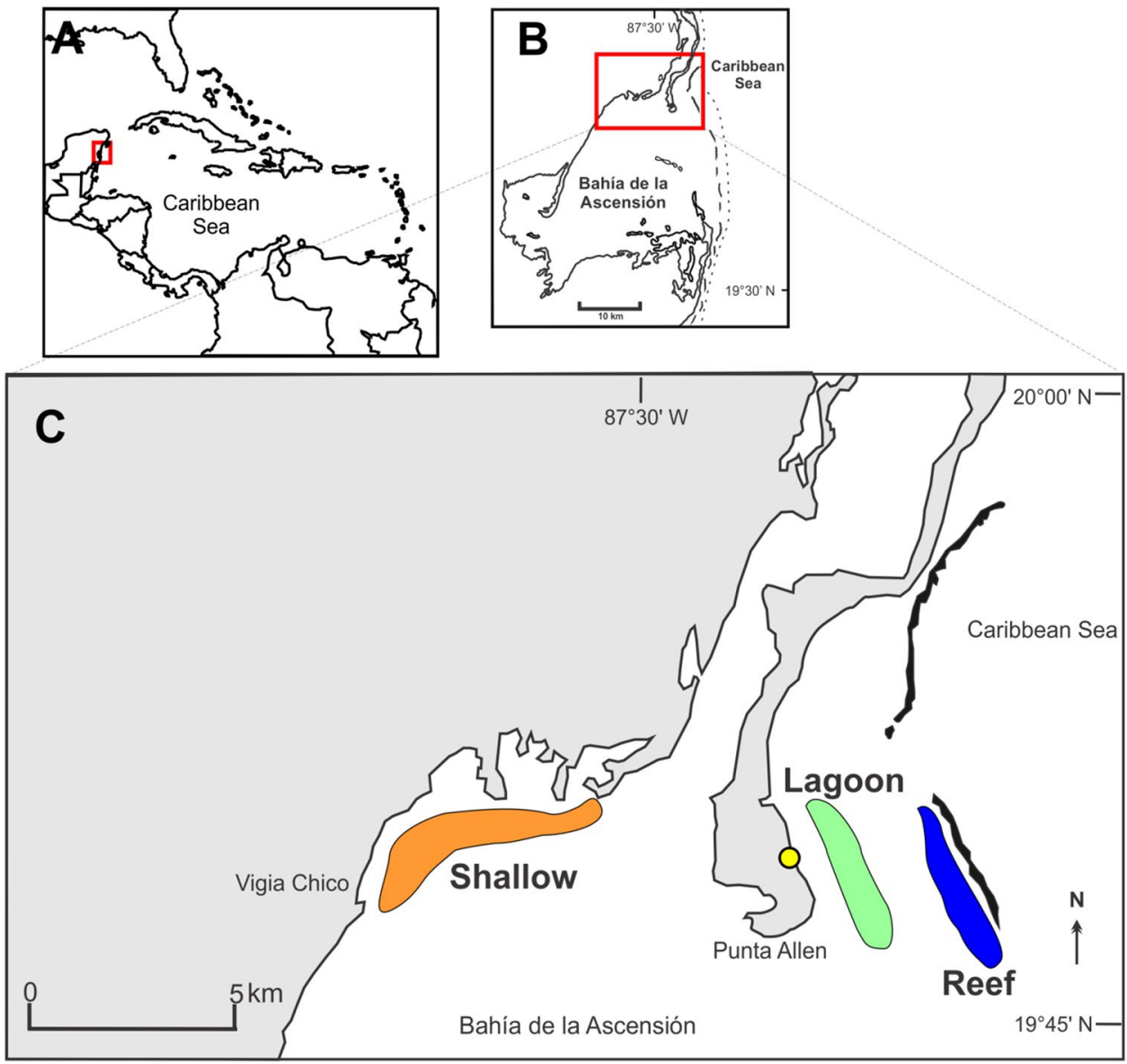

portion of the reef lagoon located between Punta Allen and the reef (hereafter "Lagoon", centered at $19^{\circ} 47^{\prime} 34.68^{\prime \prime} \mathrm{N}$, $87^{\circ} 27^{\prime} 10.02^{\prime \prime} \mathrm{W}$ ), and a shallow, inner coastal zone far from the reef (hereafter "Shallow", centered at $19^{\circ} 46^{\prime} 46.06^{\prime \prime} \mathrm{N}$, $87^{\circ} 34^{\prime} 59.10^{\prime \prime} \mathrm{W}$ ) (see Fig. 1). Areas were chosen that included casitas, as these structures harbor lobsters over a wide size range, from juveniles to adults. Casitas were chosen at random, and once searched, were marked to ensure they were not re-sampled. In addition to sampling lobsters, the three sampling zones were each characterized based on the following criteria: percent cover of benthic community components, habitat complexity, and diversity of macroinvertebrate communities. SCUBA diving was used to conduct all sampling activities.

\section{Habitat characterization}

Within each sampling zone, 7 transects were laid, each $25 \mathrm{~m}$ in length and marked every $50 \mathrm{~cm}$. Transects were laid parallel to the reef and the shore. The point intercept method (Álvarez-Filip et al. 2011) was used to estimate the percentage of cover for each of the following benthic components: sand, seagrasses, erect macroalgae, coralline algae, sponges, rubble, calcareous pavement, soft corals, live hard corals, and dead coral. This was done by recording the type of benthic component observed below each mark (=50 estimates per transect). Because points are essentially dimensionless, this method is considered the least biased and most repeatable for determining cover (Elzinga et al. 1998).

Next, 3 quadrats, $2 \mathrm{~m} \times 2 \mathrm{~m}$ each, were laid at the beginning, middle and end of each transect to assess habitat complexity using the habitat assessment score (HAS, see Gratwicke and Speight 2005; Lozano-Álvarez et al. 2017). HAS provides an overall structural complexity value by visually evaluating six variables of the local topography (rugosity, variety of growth forms, height, refuge size categories, percentage of live cover, and percentage of hard substratum). Each variable is assigned a score between 1 and 5 (from smallest or lowest to largest or highest), and the sum of the individual scores is the HAS. Therefore, a score of 6 would represent the least complex habitats and a score of 30 would represent the most complex habitats. The HAS was obtained by adding the scores of all components per quadrat. The HAS score, a qualitative metric, has the advantage that it can be applied in habitats from simple (e.g., sand) to very complex (e.g., coral reefs) (Gratwicke and Speight 2005). 


\section{Assessment of macroinvertebrate biodiversity}

To examine the potential relationship between the invertebrate community and the presence and prevalence levels of $\mathrm{PaV} 1$ and/or $C$. solearis at each zone, conspicuous invertebrates (those visible above the sand or fauna) were identified and quantified within the same $2 \mathrm{~m} \times 2 \mathrm{~m}$ quadrats used to assess habitat complexity. All underwater identifications were conducted by two scientific observers thoroughly trained prior to the samplings. Training was achieved by repeatedly studying an extensive guide of local invertebrate species created in our lab from photos and drawings obtained from many different sources (e.g., Stanley 1970; Chace 1972; Abbot 1974; Williams 1984; Abele and Kim 1986; Wagner 1990; Humman 1994; Hendler et al. 1995; García-Cubas et al. 1999; Medina et al. 2006; Ng et al. 2008; Laguarda-Figueras et al. 2009; McLaughlin et al. 2010; de Grave and Fransen 2011; Diez García and Jover Capote 2015; Carmona-Suárez and Poupin 2016), followed by direct identification in the field during preliminary dives, with the results being cross-checked between both divers (Lessios 1996; González-Gómez et al. 2018).

\section{Lobster sampling}

The fishing cooperative allowed us to sample lobsters as necessary provided we did not kill them. Therefore, assessment of parasites in lobsters was only visually conducted although, in the case of PaV1, we also extracted hemolymph from lobsters for PCR assays. All lobsters encountered beneath casitas along and around the transects were collected with hand nets. Nets containing lobsters were fastened to the edge of the boat with lobsters remaining in the water to avoid exposure to air. Lobsters were sexed, measured (carapace length, CL, from the inter-orbital notch to the rear end carapace, in millimeter), and carefully examined for clinical signs of infection with PaV1 (milky hemolymph, visible through the translucent membrane between the carapace and abdomen, Candia-Zulbarán et al. 2012) and for the presence of $C$. solearis cysts (obvious to the naked eye as small spheres of $\sim 1 \mathrm{~mm}$ in diameter in the muscles of the abdomen, visible through the translucent membrane between the carapace and the abdomen, or through the relatively thin cuticle of the ventral side of the abdomen, Gómez del Prado et al. 2003). Although it was not possible to dissect lobsters, we were confident that the cysts belonged to C. solearis, because decapod populations (except for brachyuran crabs) tend to harbor only one species of trematode (Thieltges et al. 2009) and, in previous studies, all metacercariae obtained from cysts in tails of $P$. argus were identified as $C$. solearis (Grano-Maldonado and Álvarez-Cadena 2010; Cruz-Quintana 2012). Following measurements, $200 \mu \mathrm{l}$ hemolymph was taken from the base of the fifth pair of pereopods using a 30-gauge sterile needle and $1 \mathrm{ml}$ syringe, after disinfection of the puncture site with $70 \%$ ethanol. Hemolymph samples were fixed immediately in ice-cold $96 \%$ ethanol, transported to the laboratory and frozen at $-20{ }^{\circ} \mathrm{C}$. Lobsters were returned to the capture site.

\section{Hemolymph surveillance of PaV1}

\section{DNA extraction}

DNA was extracted from $\sim 200 \mu$ lof hemolymph/ethanol mixture ( $25 \mathrm{mg}$ of hemolymph) with the Wizard genomic DNA purification kit (Promega) following a slightly modified manufacturer's protocol (Online Resource 1). DNA eluted was used as the template for polymerase chain reaction (PCR). Haemolymph DNA extraction was optimized to ensure detection of PaV1 using known, positive controls initially derived from $P$. argus, confirmed by sequencing. DNA extractions were verified by running $1 \mu$ l DNA mixed with $4 \mu$ Promega Green GoTaq ${ }^{\circledR} 5 \times$ Flexi Buffer on a $1.5 \%$ agarose gel.

\section{PCR conditions}

All PCRs were carried out using primers synthesized by Sigma and performed on a ${ }^{3}$ Prime Personal Thermal Cycler (Techne, UK) before being visualized on a 1.5\% agarose gel. To test for the presence of PaV1 in lobsters, a PCR was performed using known, specific primers for PaV1 (45aF: TTC CAG CCC AGG TAC GTA TC; and 543aR: AAC AGA TTT TCC AGC AGC GT) that amplify a region of 499 bp (Montgomery-Fullerton et al. 2007). All PCR reactions were carried out in a total volume of $10 \mu \mathrm{l}$ containing $1 \mu \mathrm{l}$ extracted DNA (50-200 $\mathrm{ng} / \mu \mathrm{l}), 0.33 \mathrm{mM}$ of each primer $45 \mathrm{aF}$ and 543aR, $2.5 \mathrm{mM} \mathrm{MgCl} 2$ (Promega), $0.6 \times$ Green GoTaq ${ }^{\circledR} 5 \times$ Flexi Buffer (Promega), $0.4 \mathrm{mM}$ dNTP mixture (Promega), and $0.75 \mathrm{u} \mathrm{GoTaq}^{\circledR}$ Flexi DNA Polymerase (Promega).

\section{Statistical analyses}

\section{Habitat characterization}

The data of structural complexity (HAS score) were analyzed to verify the normality and homoscedasticity using D'Agostino-Pearson's normality test. As these assumptions were not met, comparison of values between zones was performed using the Kruskal-Wallis test followed by Dunn's multiple comparisons test (Dunn 1964), all using a significance level of 95\%. For these analyses, GraphPad Prism 7.0 was used.

The percent data on the cover of benthic components were logit transformed (Warton and Hui 2011) and 
subjected to a principal component analysis (PCA) using the software PAST v.3.09 (Hammer et al. 2001). The transformed data for each benthic component were then compared among zones with independent one-way analysis of variance (ANOVA) using a general linear model (GLM) approach (Rutherford 2001).

\section{Macroinvertebrate biodiversity}

For each sampling zone, the following ecological indices were estimated: species richness ( $S$, number of species), Shannon-Wiener's diversity $\left(H^{\prime}\right)$, Pielou's evenness $\left(J^{\prime}\right)$ and Simpson's dominance $(D) . S$ is an informative index as it is the basis of biodiversity estimates, whereas $H^{\prime}, J^{\prime}$ and $D$ are compound indices (i.e., indices that combine richness and abundance of species) that provide a greater ability to discriminate sites than $S$ alone (Morris et al. 2014). Each index was compared among zones with a separate one-way ANOVA using a GLM approach.

Differences in community composition between sampling zones were analyzed by non-metric multidimensional scaling (MDS) using the Bray-Curtis similarity measure on a fourth root transformation of the abundance data (Clarke 1993). The significance of the observed differences among zones was further tested with a one-way analysis of similarity (ANOSIM), which provides an $R$ value, typically between 0 and 1 . Values close to 0 are indicative of only a little difference, whereas values close to 1 are indicative of a large difference in sample composition (Clarke and Warwick 2001). However, as the stress value of the 2D MDS plot was moderately high (see Results), results from this plot were cross-checked against those from a cluster analysis with group average linkage (Clarke and Warwick 2001; Clarke and Gorley 2015). The significance of the cluster findings was further tested with a similarity profile analysis (SIMPROF), which tests the null hypothesis that the set of samples contains no multivariate structure that can be further examined (Clarke et al. 2008). Finally, a similarity percentage analysis (SIMPER) was performed to identify those species that were more important in creating the observed pattern of similarity (Clarke 1993). PRIMER 6 v6.1.9 (PRIMER-E Ltd) software was used to carry out these analyses.

\section{Lobster size distribution}

Size distribution of lobsters was plotted per zone in 5-mm increments. The data did not meet the assumption of normality; therefore, a Kruskal-Wallis test with a significance level of 0.05 was used to compare lobster size among zones.

\section{Disease ecology}

Prevalence (the percentage of infected lobsters) was estimated for (a) lobsters clinically infected with PaV1 (i.e., lobsters exhibiting gross signs as described in methodology), (b) lobsters testing positive for PaV1 via PCR, not necessarily exhibiting signs of disease (i.e. those picked up via the highly sensitive PCR method), and (c) lobsters observed harboring at least one cyst of $C$. solearis, simply referred to as trematodes. In all cases, 95\% confidence intervals were computed using Wilson's score method with continuity correction (Newcombe 1998).

Binomial logistic regression models with logit link functions (Quinn and Keough 2002) were used to determine whether specific predictor variables had a significant effect on the probability of finding lobsters clinically infected with $\mathrm{PaV} 1$, lobsters testing positive to PaV1 infection by PCR, and lobsters infected with $C$. solearis. The predictor variables were size (CL, covariate) and zone (categorical factor with three levels: Reef, Lagoon and Shallow, with Shallow as the reference level). In the models for lobsters testing positive to PaV1 by PCR and lobsters infected with C. solearis, the effect of the presence of the other parasite in the same lobster (i.e., presence of $C$. solearis for the model examining probability of infection with $\mathrm{PaV} 1$ by PCR, and viceversa) was also examined (categorical factor with two levels: presence and absence, with presence as the reference level). It was not possible to test the effect of $C$. solearis on the probability of clinical infection with PaV1, because lobsters with both $C$. solearis and clinical signs of PaV1 were not present at all zones. However, Briones-Fourzán et al. (2016) pooled the data from all their sampling sites to test the effect of lobster size and the presence of clinical signs of PaV1 on the probability of finding lobsters with trematodes; therefore, for comparative purposes, this was also done in the present study. All logistic models were run in the software Statistica v.10 (StatSoft, Inc., USA).

\section{Results}

\section{Habitat characterization}

\section{Habitat complexity}

The HAS score showed that the three zones in Bahía de la Ascensión were distinctly separated (Fig. 2). Dunn's multiple comparisons test revealed that the most significant difference in habitat complexity was between Shallow and Lagoon $(p<0.0001$, mean rank diff. $=-28.83)$ followed by Shallow vs. Reef ( $p=0.0051$, mean rank diff. $=-17.6$ ). Lagoon vs. Reef, however, was not significantly different $(p=0.1348$, mean rank diff. $=11.24)$. This indicates 


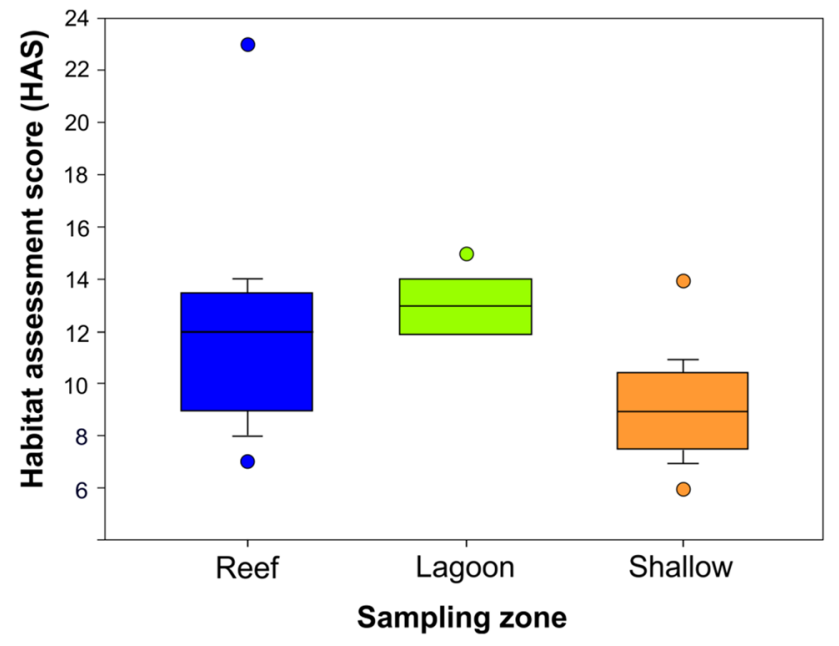

Fig. 2 Box plot of habitat assessment score (HAS) on three sampling zones in Bahía de la Ascensión: Reef (blue), Lagoon (green) and Shallow (orange). The lower and higher boundaries of the box indicate the 25th and 75th percentiles, respectively. The horizontal line within the box marks the median. Whiskers (error bars) above and below the box indicate the 90th and 10th percentiles. Dots denote outliers

that Shallow was the zone with the least complex habitat, with a lower overall HAS score compared to the other two zones.

\section{Cover of benthic components}

The first two axes of the PCA of the percent cover of benthic components explained $51.3 \%$ and $18.3 \%$ of the cumulative variance, respectively. The first axis was positively related with coralline algae and seagrasses (loadings 0.458 and 0.422 , respectively) and negatively related with calcareous pavement and sand ( -0.498 and -0.426 , respectively), whereas the second axis was positively related with rubble (0.648) and negatively related with seagrasses $(-0.526)$ (Fig. 3). Transects on Shallow were distinctly separated from transects on the other two zones along the first axis, whereas transects on Reef and transects on Lagoon differed mostly along the second axis (Fig. 3). The GLMs comparing each benthic component among zones revealed that all components (except rubble) differed significantly with zone (Table 1). In particular, Lagoon was dominated by seagrass $(67.7 \%$ of total cover) followed at a distance by sand $(11.7 \%)$, whereas Shallow was dominated by sand $(56.9 \%$ of total cover) followed by calcareous pavement $(17.4 \%)$ and macroalgae (16.6\%). In contrast, dominance was not so pronounced in Reef, which exhibited a $38 \%$ cover by seagrass, followed by $18.6 \%$ cover of coralline algae and by several components with coverages between 10 and 13\% (sand, dead coral, rubble) (Table 1).

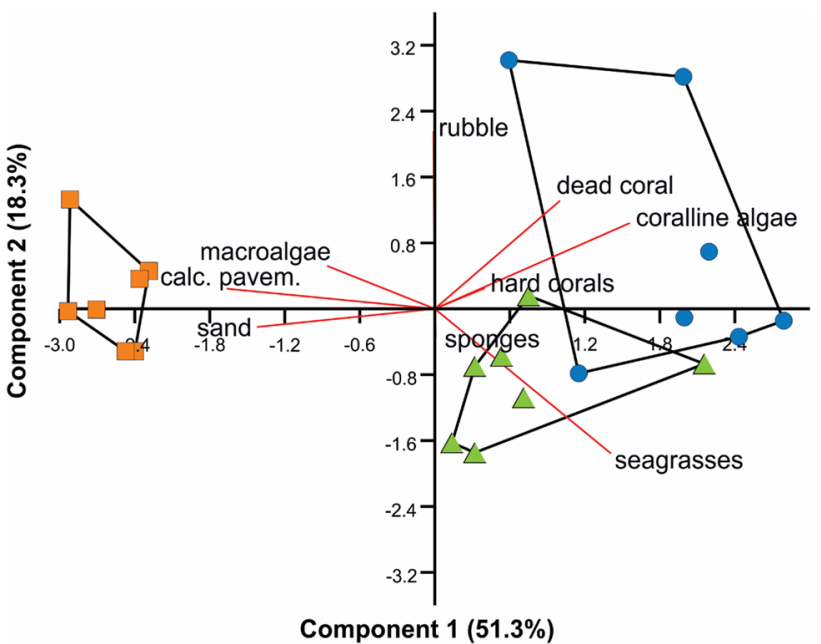

Fig. 3 Principal component analysis (PCA) of the cover of benthic components. Bi-plot on logit transformation of percent cover of benthic components over the three sampling zones in Bahía de la Ascensión, Reef (blue dots), Lagoon (green triangles), and Shallow (orange squares). Each symbol represents a transect ( $N=7$ per zone)

\section{Assessment of macroinvertebrate community}

Identification of conspicuous invertebrates yielded 63 taxa in total ( 2 anemones, 6 polychaetes, 25 crustaceans, 7 echinoderms, and 23 mollusks), with 35 taxa in Reef, 38 in Lagoon, and 20 in Shallow (Online Resource 2). Most taxa were identified to species level. Ecological indices $S$, $H^{\prime}$ and $J^{\prime}$ were higher in Reef and Lagoon than in Shallow, but $D$ was far greater in Shallow than in the other two zones (Table 2). The 2D MDS ordination plot had a relatively high stress value (0.19); therefore, conclusions derived from this plot were cross-checked against those from the cluster analysis and SIMPROF test (Clarke and Warwick 2001) (Fig. 4a). The resulting plot (Fig. 4b) shows that, at 20\% similarity, all quadrats from Reef and Lagoon formed one group, whereas quadrats from Shallow formed two groups. This was mainly due to a high abundance of the yellow mussel Brachidontes modiolus in three of the quadrats on Shallow. At $30 \%$ similarity, several groups with variable degrees of overlap were formed within each zone, but Shallow remained distinctly separated from the other two zones. This was confirmed by ANOSIM, which yielded an overall $R=0.704$. $R$ values were higher in pairwise comparisons involving Shallow (vs Reef, $R=0.747$; vs Lagoon, $R=0.807$ ), than between Reef and Lagoon $(R=0.514)$.

Results of SIMPER (Online Resource 3) showed a higher average similarity among quadrats within Shallow (42.4\%) and within Lagoon (41.4\%) than among quadrats within Reef $(33.2 \%)$. A cumulative similarity of $\sim 90 \%$ among quadrats was accounted for by nine species in Lagoon and eight in Reef, but only by four species in Shallow. Average 
Table 1 Percent cover (mean $\pm 95 \%$ confidence interval) of benthic constituents on three zones in Bahía de la Ascensión (Reef, Lagoon, Shallow; $N=7$ transects per zone)

\begin{tabular}{llllrrr}
\hline Benthic component & Reef & Lagoon & Shallow & \multicolumn{1}{c}{ F } & $d f$ & \multicolumn{1}{c}{$p$} \\
\hline Seagrasses & $38.0 \pm 15.6^{\mathrm{a}}$ & $67.7 \pm 6.0^{\mathrm{b}}$ & $6.0 \pm 2.8^{\mathrm{c}}$ & 28.725 & 2,18 & $<0.001$ \\
Erect macroalgae & $5.1 \pm 5.9^{\mathrm{a}}$ & $9.4 \pm 2.7^{\mathrm{ab}}$ & $16.6 \pm 7.4^{\mathrm{b}}$ & 6.889 & 2,18 & 0.006 \\
Coralline algae & $18.6 \pm 5.6^{\mathrm{a}}$ & $4.6 \pm 4.7^{\mathrm{b}}$ & $0^{\mathrm{b}}$ & 24.602 & 2,18 & $<0.001$ \\
Sand & $13.4 \pm 10.0^{\mathrm{a}}$ & $11.7 \pm 4.3^{\mathrm{a}}$ & $56.9 \pm 10.4^{\mathrm{b}}$ & 14.006 & 2,18 & $<0.001$ \\
Sponges & $0^{\mathrm{a}}$ & $2.3 \pm 1.8^{\mathrm{b}}$ & $0.3 \pm 0.6^{\mathrm{ab}}$ & 5.179 & 2,18 & 0.017 \\
Rubble & $10.3 \pm 13.7^{\mathrm{a}}$ & $3.7 \pm 3.5^{\mathrm{a}}$ & $2.9 \pm 3.6^{\mathrm{a}}$ & 0.084 & 2,18 & 0.920 \\
Live hard coral & $3.1 \pm 1.7^{\mathrm{a}}$ & $0.6 \pm 0.7^{\mathrm{b}}$ & $0^{\mathrm{b}}$ & 11.784 & 2,18 & 0.001 \\
Dead coral & $11.4 \pm 6.0^{\mathrm{a}}$ & $0^{\mathrm{b}}$ & $0^{\mathrm{b}}$ & 49.351 & 2,18 & $<0.001$ \\
Calcareous pavement & $0^{\mathrm{a}}$ & $0^{\mathrm{a}}$ & $17.4 \pm 6.3^{\mathrm{b}}$ & 154.103 & 2,18 & $<0.001$ \\
\hline
\end{tabular}

Analyses of variance (ANOVA, $\alpha=0.05$ ) were done on logit-transformed data using a general lineal model approach. Along each row, different superscripts indicate significantly different means
Table 2 Ecological indices for macroinvertebrates by quadrat per zone

\begin{tabular}{llll}
\hline $\begin{array}{l}\text { Ecological } \\
\text { index }\end{array}$ & Reef & Lagoon & Shallow \\
\hline$S$ & $6.80 \pm 1.38^{\mathrm{a}}$ & $8.52 \pm 0.74^{\mathrm{b}}$ & $3.86 \pm 0.62^{\mathrm{c}}$ \\
$H^{\prime}$ & $1.65 \pm 0.18^{\mathrm{a}}$ & $1.85 \pm 0.20^{\mathrm{a}}$ & $0.91 \pm 0.19^{\mathrm{b}}$ \\
$D$ & $0.19 \pm 0.04^{\mathrm{a}}$ & $0.20 \pm 0.08^{\mathrm{a}}$ & $0.48 \pm 0.10^{\mathrm{b}}$ \\
$J^{\prime}$ & $0.91 \pm 0.03^{\mathrm{a}}$ & $0.87 \pm 0.08^{\mathrm{ab}}$ & $0.73 \pm 0.11^{\mathrm{b}}$ \\
\hline
\end{tabular}

Mean value $( \pm 95 \%$ confidence interval) of species richness $(S)$, Shannon-Wiener diversity $\left(H^{\prime}\right)$, evenness $\left(J^{\prime}\right)$, and dominance $(D)$ of macroinvertebrates on three sampling zones in Bahía de la Ascensión, México (Reef, Lagoon, Shallow). For each index, different superscripts indicate significantly different means (ANOVA, $\alpha=0.05$ )

dissimilarity was higher between Shallow and Reef (89\%), and between Shallow and Lagoon (87.4\%), than between Reef and Lagoon (77.7\%). The five most common species in Reef included two ophiurids (the harlequin brittle star Ophioderma appressa and the ruby brittle star $O$. rubicunda), two decapods (the nodose clinging crab Mithraculus coryphe and the hermit crab Pagurus brevidactylus), and one gastropod (the stocky cerith Cerithium litteratum). The five most common species in Lagoon were three gastropods $(C$. litteratum, the silky tegula Tegula fasciata, and the longspine star shell Lithopoma phoebium) and two decapods ( $P$. brevidactylus and the blue-legged hermit crab Clibanarius tricolor). Finally, the five more common species in Shallow included two decapods ( $P$. brevidactylus and the brownbanded hermit Pagurus annulipes), two bivalves (the crossbarred venus Chione cancellata and the yellow mussel $B$. modiolus), and a polychaete (the spaghetti worm Eupolymnia crassicornis) (Online Resource 3 ).

\section{Lobster size distribution}

In total, 430 lobsters were collected (132 in Reef, 150 in Lagoon, and 148 in Shallow) with an overall size range of 12.2-131.9 mm CL. The size distribution of lobsters exhibited two modes in Shallow and Lagoon (Fig. 5) and the data did not meet the assumption of normality. There was a significant difference in lobster sizes among zones (Kruskal-Wallis test, $H_{2}=115, p<0.0001$ ), with Dunn's multiple comparisons test revealing that Reef lobsters were significantly larger than those found in Lagoon and in Shallow, but also the lobsters in Lagoon being significantly larger than those in Shallow (mean rank diff. Shallow vs. Lagoon $=-37.73, p=0.0264$; Shallow vs. Reef $=-154.5, p<0.0001 ;$ Lagoon vs. Reef $=-116.8$, $p<0.0001$ ).

\section{Disease ecology}

As a whole, across all zones, significantly more lobsters were found infected with PaV1 using PCR (Fig. 6). However, the pattern differed between zones. Significantly more lobsters residing in Lagoon were infected with PaV1, both clinically and detected via PCR, than in Reef and Shallow. Fewer lobsters infected with trematodes occurred in Lagoon than in Reef and Shallow (Fig. 6).

The logistic regression models showed that the probability of finding lobsters with clinical signs of PaV1 infection decreased with increasing size of lobster and was significantly higher in Lagoon than in Shallow (odds ratio, OR: 1.95), but was similar between Reef and Shallow (Table 3A). The probability of finding lobsters testing positive to $\mathrm{PaV} 1$ by PCR also decreased with increasing lobster size and was not affected by the presence of $C$. solearis in lobsters, but was significantly higher in Lagoon (OR: 1.97) and Reef (OR: 1.77) than in Shallow (Table 3B). By contrast, the probability of infection with trematodes increased with increasing lobster size, but was not affected by the presence of PaV1 and did not vary significantly with zone (Table 3C). Upon pooling the data from all sampling zones, the probability of finding lobsters with trematodes increased significantly 
Fig. 4 Invertebrate community structure in benthic samples from three sampling zones in Bahía de la Ascensión: Reef (blue dots), Lagoon (green triangles), and Shallow (orange squares). a Hierarchical clustering (group average linkage) and b non-metric multidimensional scaling plots showing groups of quadrats within $20 \%$ (continuous line) and 30\% (broken gray line) similarity contours given by sequence of SIMPROF tests on dendrograms from a. Analyses were done using Bray-Curtis similarity and fourth root transformations. Each symbol denotes a quadrat $(N=21$ per zone)

Fig. 5 Size frequency distribution of individual lobsters caught in the three chosen zones within Bahía de la Ascensión; Shallow (orange, $N=148$ ), Lagoon (green, $N=150$ ) and Reef (blue, $N=132$ )
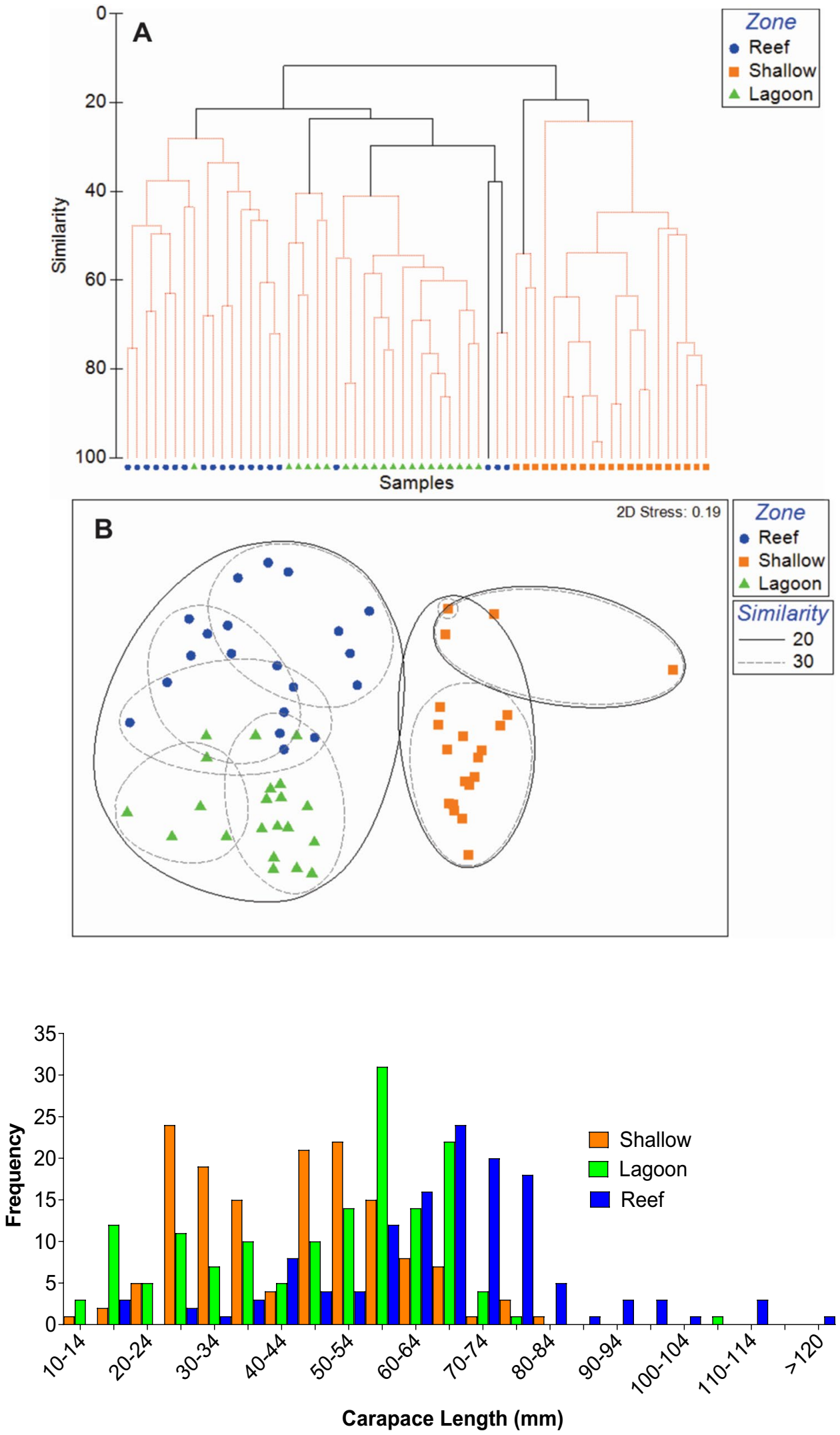


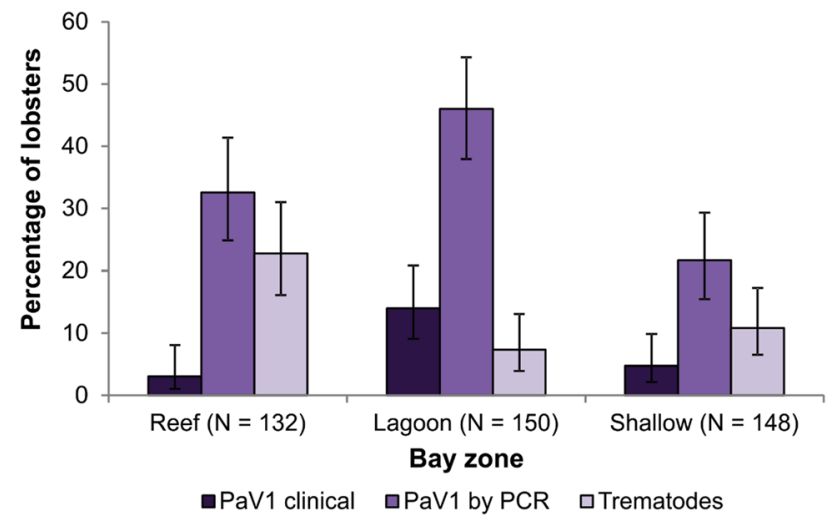

Fig. 6 Panulirus argus. Clinical prevalence of PaV1 (percent of lobsters visibly infected, i.e., diseased) (dark purple columns), prevalence of infection with PaV1 as detected by PCR (medium purple columns), and prevalence of infection with metacercariae of the trematode Cymatocarpus solearis (light purple columns) in lobsters sampled from casitas in three zones in Bahía de la Ascensión, Mexico. Numbers in parentheses are sample sizes; error bars denote $95 \%$ confidence intervals

with size but was not affected by the presence of clinical signs of PaV1 (Table 4A) or by the presence of PaV1 via PCR (Table 4B).

\section{Discussion}

This investigation aimed to increase insight into the complex relationships between habitat characteristics and parasites of spiny lobsters. An inverse relationship between lobster size and the probability of infection with PaV1 was found, which is consistent with findings of previous studies (e.g., Butler et al. 2008; Behringer et al. 2011; Candia-Zulbarán et al. 2012; Briones-Fourzán et al. 2012; Huchin-Mian et al. 2013). However, even after accounting for the significant effect of size on the probability of infection with $\mathrm{PaV} 1$, such probability was highest in Lagoon, where seagrass was far more abundant, supporting the idea first put forward by Briones-Fourzán et al. (2012) that marine vegetation could be an environmental reservoir for PaV1. Seagrass meadows and macroalgal beds trap particles, because they attenuate water flow velocity (Scoffin 1970; Peterson et al. 2004). Thus, they have natural filtration abilities, which can, for example, reduce the abundance of bacteria reaching coral reefs (Lamb et al. 2017). This suggests that marine vegetation can concentrate viral particles, therefore potentially increasing the risk of infection for local lobsters. In contrast, results concerning $C$. solearis are not consistent with those of the prior study by Briones-Fourzán et al. (2016). These authors found the highest levels of $C$. solearis prevalence in their "Vigía Chico" zone, where the zone herein called Shallow is located, whereas the present study found no significant effect of zone on the probability of infection with $C$. solearis. However, both studies found a positive relationship between lobster size and probability of infection with $C$. solearis.
Table 3 Estimates for logistic regression analyses testing the effects of size (carapace length, $\mathrm{mm}$ ) and sampling zone (three levels: Reef, Lagoon, Shallow; reference level: Shallow) on the probability of finding spiny lobsters Panulirus argus: (A) clinically infected with $\mathrm{PaV} 1$, (B) testing positive to $\mathrm{PaV} 1$ by PCR, and (C) infected with metacercariae of the trematode Cymatocarpus solearis, in Bahía de la Ascensión, Mexico

\begin{tabular}{|c|c|c|c|c|c|c|}
\hline Effect & Level & Estimate & SE & Wald & $p$ & Odds ratio $(95 \% \mathrm{CI})$ \\
\hline \multicolumn{7}{|c|}{ (A) PaV1 clinical infection } \\
\hline Intercept & & 0.369 & 0.544 & 0.461 & 0.497 & \\
\hline Size & & -0.070 & 0.013 & 28.839 & $<0.001$ & $0.93(0.91,0.96)$ \\
\hline \multirow[t]{2}{*}{ Zone } & Reef & 0.055 & 0.401 & 0.019 & 0.892 & $1.06(0.48,2.32)$ \\
\hline & Lagoon & 0.665 & 0.284 & 5.480 & 0.019 & $1.94(1.11,3.39)$ \\
\hline \multicolumn{7}{|c|}{ (B) PaV1 by PCR } \\
\hline Intercept & & 0.396 & 0.426 & 0.863 & 0.353 & \\
\hline Size & & -0.024 & 0.007 & 12.917 & $<0.001$ & $0.98(0.96,0.99)$ \\
\hline Trematodes & & 0.126 & 0.221 & 0.326 & 0.568 & $1.13(0.74,1.75)$ \\
\hline \multirow[t]{2}{*}{ Zone } & Reef & 0.571 & 0.271 & 4.439 & 0.035 & $1.77(1.04,3.01)$ \\
\hline & Lagoon & 0.677 & 0.286 & 5.605 & 0.018 & $1.97(1.12,3.44)$ \\
\hline \multicolumn{7}{|l|}{ (C) Trematodes } \\
\hline Intercept & & -4.784 & 0.658 & 52.828 & $<0.001$ & \\
\hline Size & & 0.047 & 0.010 & 20.709 & $<0.001$ & $1.05(1.03,1.07)$ \\
\hline PaV1 by PCR & & 0.127 & 0.223 & 0.325 & 0.569 & $1.14(0.73,1.76)$ \\
\hline \multirow[t]{2}{*}{ Zone } & Reef & 0.312 & 0.286 & 1.193 & 0.275 & $1.37(0.78,2.39)$ \\
\hline & Lagoon & -0.237 & 0.291 & 0.665 & 0.415 & $0.79(0.45,1.39)$ \\
\hline
\end{tabular}

In $\mathrm{B}$ and $\mathrm{C}$, the effect of the other parasite (trematodes in $\mathrm{B}, \mathrm{PaV} 1$ by PCR in $\mathrm{C}$ ) was also tested (reference level: present) 
Table 4 Estimates for logistic regression analyses testing the effects of size (carapace length, $\mathrm{mm}$ ) and (A) presence/absence of clinical signs of PaV1 (reference level: presence), (B) testing positive/nega- tive to PaV1 by PCR (reference level: positive) on the probability of finding spiny lobsters infected with trematodes $(N=430$; samples from all zones pooled)

\begin{tabular}{|c|c|c|c|c|c|c|}
\hline Effect & Level & Estimate & SE & Wald & $p$ & Odds ratio $(95 \% \mathrm{CI})$ \\
\hline \multicolumn{7}{|l|}{ (A) } \\
\hline Intercept & & -4.570 & 0.606 & 56.801 & $<0.001$ & \\
\hline Size & & 0.047 & 0.009 & 28.645 & $<0.001$ & $1.05(1.03,1.07)$ \\
\hline PaV1 signs & Absence & -0.073 & 0.392 & 0.035 & 0.852 & $0.93(0.43,2.00)$ \\
\hline \multicolumn{7}{|l|}{ (B) } \\
\hline Intercept & & -4.625 & 0.564 & 67.232 & $<0.001$ & \\
\hline Size & & 0.047 & 0.009 & 29.291 & $<0.001$ & $1.05(1.03,1.07)$ \\
\hline PaV1 by PCR & Negative & 0.050 & 0.165 & 0.091 & 0.762 & $1.05(0.76,1.45)$ \\
\hline
\end{tabular}

\section{Habitat characterization}

The habitat characterization revealed substantial differences among the three sampling zones. The Reef zone had the greatest variability in both habitat complexity and cover of benthic components, but seagrass had the greatest cover (38\%). These features reflect the location of this zone along the back reef, i.e., the interface between the reef lagoon and the coral reef structure. Results for Lagoon and Shallow were similar to those of Briones-Fourzán et al. (2012) for their larger sampling zones "Punta Allen" and "Vigía Chico", which encompass Lagoon and Shallow, respectively. The Lagoon zone was vastly dominated by marine vegetation consisting mainly of seagrass, with interspersed macroalgae. In contrast, the Shallow zone consisted mostly of rather featureless, shallow bottoms, either bare rock ("calcareous pavement") or covered with fine sand, or with small patches of short macroalgae.

\section{Invertebrate biodiversity}

The characterization of the invertebrate community is an important step into the search for potential vectors for $\mathrm{PaV} 1$ and first intermediate hosts for $C$. solearis. Most of the invertebrate species identified in the present study have been recorded in benthic communities of similar coastal systems in the wider Caribbean region (e.g., McNulty et al. 1962; Alcolado 1990), but substantial differences in community composition occurred among the three sampling zones. The invertebrate community differed more substantially in Shallow due to the dominance of two bivalves that were not recorded in either Reef or Lagoon, the mussel Brachidontes modiolus and the clam Chione cancellata. The former is a highly gregarious species that attaches to hard bottoms (Fields and Moore 1983) and was patchily distributed, whereas the latter is found in sandy and silty bottoms (McNulty et al. 1962). The particular habitat characteristics and invertebrate community composition of the
Shallow zone are related to its location in the inner bay area, which is very shallow ( $<2 \mathrm{~m}$ on average, Briones-Fourzán et al. 2012) and highly exposed to runoff and underground freshwater input (Medina-Gómez et al. 2014). In contrast, the habitat characteristics and invertebrate community composition of the Reef and Lagoon zones, located in the outer bay area, are more typical of coral reef systems, with higher richness and lower dominance values. These zones shared many species but differed in the relative abundance of species. However, the hermit crab Pagurus brevidactylus was one of the most abundant decapods in all three zones, whereas Cerithium litteratum and Tegula fasciata were the two most abundant gastropods in Reef and Lagoon. These species inhabit a wide range of habitats in other Caribbean reef and bay areas (e.g., Alcolado 1990).

\section{Lobster size distribution}

In Bahía de la Ascensión, the mean size of $P$. argus has been typically found to be larger in reef habitats and smaller in seagrass habitats of the outer bay area (i.e., between the land points and the reef; e.g., Lozano-Álvarez et al. 1991; Briones-Fourzán et al. 2012, 2016; Candia-Zulbarán et al. 2012; Huchin-Mian et al. 2013). However, the mean size of lobsters in the inner bay area, where the Shallow zone was located, appears to vary widely in time relative to zones in the outer bay area, being larger in some years (e.g., LozanoÁlvarez et al. 1991; Briones-Fourzán et al. 2012, 2016; Candia-Zulbarán et al. 2012; Huchin-Mian et al. 2013) and smaller in other years (Eggleston et al. 1990; LozanoÁlvarez et al. 1991; Eggleston and Lipcius 1992, the present study). Although a potential relationship with disease dynamics cannot be dismissed, the temporal variation in the mean size of lobsters in the inner bay is more likely to be related with movement pulses of lobsters triggered by the broad variation in environmental conditions typical of this shallow area, which is more vulnerable to storm waves and more exposed to underground freshwater input and high 
evaporation (Arellano-Méndez et al. 2011; Medina-Gómez et al. 2014). Thus, when salinities decline in the inner bay, large local lobsters tend to migrate towards the outer bay area (Lozano-Álvarez et al. 1991), which is more stable in environmental conditions (Medina-Gómez et al. 2014).

\section{PaV1}

PaV1 has predilection for juvenile spiny lobsters (Shields and Behringer 2004), thus explaining why the probability of infection with PaV1 (both based on clinical signs and detected via PCR) significantly decreased with increasing size of lobsters. These results are consistent with previous studies concerning PaV1 in Bahía de la Ascensión (Briones-Fourzán et al. 2012; Candia-Zulbarán et al. 2012; Huchin-Mian et al. 2013) and elsewhere (Butler et al. 2008). However, Briones-Fourzán et al. (2012) found a significantly higher probability of infection for lobsters of all sizes in densely vegetated habitats than in poorly vegetated habitats. These authors hypothesized that if $\mathrm{PaV} 1$ particles are transmitted through water (e.g., Butler et al. 2008), then their persistence might be influenced by habitat exposure to UV radiation and the degree of shading provided by the local marine vegetation, i.e., that marine vegetation could be an environmental reservoir for PaV1 (Briones-Fourzán et al. 2012). Seagrass meadows in particular can attenuate water flow velocity (Peterson et al. 2004), which could potentially cause the pooling of virions, and in the present study the probability of clinical infection with $\mathrm{PaV} 1$ was highest in Lagoon, where the cover of seagrass was far greater. Interestingly, compared to the Shallow zone, the probability of lobsters testing positive to PaV1 by PCR was higher not only in Lagoon, but also in Reef, where the largest lobsters occurred. However, the cover of seagrass was also the highest among all benthic components in Reef due to its location in the interface with the reef lagoon, and it has been previously established that lobsters $>50 \mathrm{~mm} \mathrm{CL}$, including fully mature adults, can carry $\mathrm{PaV} 1$ in their system without necessarily developing clinical signs (Behringer et al. 2012; Huchin-Mian et al. 2013). Overall, these results lend support to the hypothesis of Briones-Fourzán et al. (2012), although the presence of viable virions in seagrass meadows requires to be tested, e.g., by means of environmental DNA techniques (Taberlet et al. 2018).

To date, Panulirus argus is the only known host for PaV1. Butler et al. (2008) investigated the presence of PaV1 by means of histology in individuals of three other species sympatric with $P$. argus (the spotted spiny lobster Panulirus guttatus, the channel crab Maguimithrax spinosissimus, and the stone crab Menippe mercenaria) 90 days after inoculating them with hemolymph of a PaV1-infected lobster, but found no evidence of PaV1 in any of them. In the present study, however, none of these three species were observed in the sampling zones and, to our knowledge, there have been no other attempts to find other potential hosts or vectors for $\mathrm{PaV} 1$. The invertebrate biodiversity assessment conducted in the present study could allow screening other species for the presence of PaV1, such as the small and very abundant hermit crabs observed in the reef and lagoon zones, using molecular techniques (e.g., endpoint PCR, MontgomeryFullerton et al. 2007; qPCR, Clark et al. 2018).

\section{Cymatocarpus solearis}

In theory, the potential for trematode infection risk for lobsters may be higher in Shallow than in Reef and Lagoon, because the greater diversity of invertebrates in general and gastropods in particular in the two latter zones could result in a "dilution effect" (Civitello et al. 2015), whereby alternate hosts or predators may "intercept" miracidia (e.g., Laracuente et al. 1979) or cercariae (Thieltges et al. 2008; Orlofske et al. 2012). In the study by Briones-Fourzán et al. (2016), the probability of infection with $C$. solearis was significantly higher for lobsters in the site they called "Vigía Chico" (where the Shallow sampling zone is located) than for lobsters in two other more vegetated sites, but in the present study the sampling zone had no significant effect on this probability. However, in the study of Briones-Fourzán et al. (2016), lobsters from Vigía Chico had the largest mean size, whereas in the present study lobsters from Shallow had the smallest mean size. Also, Briones-Fourzán et al. (2016) found that the probability of infection with $C$. solearis significantly increased in the absence of clinical signs of $\mathrm{PaV} 1$, whereas no effect of presence of $\mathrm{PaV} 1$ on probability of infection by trematodes was found in the present study. These contrasting findings underline the complexity in potential relationships between lobster size, parasite infection, and features of local habitat and communities. On the other hand, as we only used visual inspection in the field, it is possible that we missed some lobsters infected with $C$. solearis, although the cysts of this parasite are large and easily detected by trained scientists. Estimating sensitivity of visual assessment of $C$. solearis prevalence would require comparing results of such assessment to results obtained via a complete dissection of a representative sample of lobsters over a broad size range. This would imply euthanizing the lobsters, which was not possible in the present study.

The characterization of the invertebrate community allowed the identification of some species that may act as first intermediate hosts for $C$. solearis and further explain its distribution. Digeneans use gastropods, bivalves, scaphopods and polychaetes as first intermediate hosts, but gastropods are the most common group (Cribb et al. 2003). All gastropods recorded in our sampling zones belong to superfamilies that have been identified as first intermediate hosts of trematodes in the order Plagiorchiida (Cribb 
et al. 2003), which includes the family Brachycoeliidae to which $C$. solearis belongs. Overall, there were 15 species of conspicuous gastropods in the 3 sampling zones, with the most abundant being Cerithium litteratum, Tegula fasciata, Cerithium sp., and Lithopoma phoebium. Only C. litteratum was present in all three sampling zones but more so in the Lagoon and Reef, whereas T. fasciata was absent in Shallow and L. phoebium was present only in Lagoon. Other gastropods moderately present in the Lagoon and Reef were L. tectum and Cittarium pica, whereas rarer species included Fasciolaria tulipa, Prunum pruinosum, Smaragdia viridis, Lobatus costatus, L. gigas, and Fissurella sp. Gastropods were overall very rare in the Shallow zone, where the mollusk fauna was rather dominated by the bivalves $B$. modiolus and $C$. cancellata. Whilst it is known that the family Brachycoeliidae does not use bivalves as first intermediate hosts (Cribb et al. 2001), other digenean metacercariae have been reported in several bivalve species (e.g., Lassalle et al. 2007). Taking this into account, C. litteratum and possibly $T$. fasciata are put forward as the most likely potential candidates for the first intermediate host of $C$. solearis.

\section{Conclusions and future work}

The present study builds upon previous studies by adding new information and providing further insight into the parasite/host system dynamics. For example, the findings of our quantitative analysis of cover of benthic components support the notion that marine vegetation could be an environmental reservoir for $\mathrm{PaV} 1$, and our logistic regression analyses provide further evidence that lobster size plays a vital role in the probability of infection by both PaV1 and C. solearis. A novel contribution of the present study was the analysis of the invertebrate community in our sampling zones, which allowed the identification of a few species as potential first intermediate host for the latter parasite and as targets for future research into potential vectors for PaV1, but also as a first step into understanding how species diversity in a given community may affect disease dynamics in these two parasite/host systems (Keesing et al. 2006; Johnson and Thieltges 2010). Since the conception of the present study, research surrounding PaV1 has progressed with new techniques which are not only able to detect, but also to quantify PaV1 in P. argus (Clark et al. 2018). In the near future, these techniques could be used to test for the presence of viable PaV1 virions in seagrass and other marine vegetation, as well as in decapod species associated with this type of habitat.

There is also much to discover surrounding $C$. solearis. First, it would be necessary to test whether $C$. litteratum, $T$. fasciata, or any other of the gastropod species herein identified indeed act as first intermediate hosts of $C$. solearis.
This could be done by subjecting the gastropods to standard techniques inducing cercarial shedding (e.g., Morton 2018), which would allow to obtain and describe the cercariae of C. solearis, which remain undescribed. Although to the best of our knowledge $C$. solearis is the only trematode found in $P$. argus, the development and incorporation of molecular diagnostics for this trematode are important to determine whether other trematodes also infect $P$. argus, and to definitively determine the first intermediate host(s) (Théron 2014) as well as the presence of $C$. solearis in lobsters without the need to euthanize them. The potential effects of $C$. solearis on $P$. argus also merit investigation. For example, from a pathological viewpoint, histology could identify some immune reactions visually, whereas from a physiological angle, biochemical assays (e.g., Davies et al. 2015) could shed more light on this issue; however, molecular diagnostics would be needed to observe transcriptomic changes to get a full assessment of immunological effects.

Acknowledgements The authors would like to thank Cecilia BarradasOrtiz and Fernando Negrete-Soto for their invaluable help in assisting with the project. The authors would also like to thank Roberto González-Gómez, Alí Espinosa-Magaña, Leslie Cid-González, and Raúl Tecalco-Rentería for assistance in the field. This project was funded by UNAM-DGAPA-PAPIIT IN-206117 Granted to PBF, and postdoctoral scholarship UNAM-DGAPA 2016-2018 Granted to CED.

\section{Compliance with ethical standards}

Conflict of interest The authors declare that they have no conflict of interest.

Human and animal rights statement This article does not contain any studies with human participants performed by any of the authors, nor were any experiments performed on captive animals. All applicable international, national and/or institutional guidelines for the care and use of animals were followed. All procedures performed in the study involving animals were in accordance with the ethical standards of Mexican law regarding maintaining animal welfare in research.

Open Access This article is distributed under the terms of the Creative Commons Attribution 4.0 International License (http://creativeco mmons.org/licenses/by/4.0/), which permits unrestricted use, distribution, and reproduction in any medium, provided you give appropriate credit to the original author(s) and the source, provide a link to the Creative Commons license, and indicate if changes were made.

\section{References}

Abbot RT (1974) American seashells: the marine Mollusca of the Atlantic and Pacific coast of North America. Van Nostrand Reinhold, New York

Abele LG, Kim W (1986) An illustrated guide to the marine decapod crustaceans of Florida. St Fla Dep Environ Regul Tech Ser 8(1):ixvii, 1-326 (Part 1), 327-760 (Part 2), Tallahassee 
Aburto-Oropeza O, Ezcurra E, Moxley J, Sánchez-Rodríguez A, Mascareñas-Osorio I, Sánchez-Ortiz C, Erisman B, Ricketts T (2015) A framework to assess the health of rocky reefs linking geomorphology, community assemblage, and fish biomass. Ecol Indic 52:353-361

Alcolado P (ed) (1990) El bentos de la macrolaguna del Golfo de Batabanó. Editorial Academia, La Habana

Álvarez-Filip L, Gill JA, Dulvy NK (2011) Complex reef architecture supports more small-bodied fishes and longer food chains on Caribbean reefs. Ecosphere 2:art118

Arellano-Méndez LU, Liceaga-Correa MA, Herrera-Silveira JA, Hernández-Nuñez H (2011) Impacto por huracanes en las praderas de Thalassia testudinum (Hydrocharitaceae) en el Caribe Mexicano. Rev Biol Trop 59:385-401

Behringer DC, Butler MJ, Shields JD (2006) Avoidance of disease by social lobsters. Nature 441:421

Behringer DC, Butler MJ IV, Shields JD, Moss J (2011) Review of Panulirus argus virus 1 - a decade after its discovery. Dis Aquat Org 94:153-160

Behringer DC, Butler MJ IV, Moss J, Shields JD (2012) PaV1 infection in the Florida spiny lobster (Panulirus argus) fishery and its effects on trap function and disease transmission. Can J Fish Aquat Sci 69:136-144

Briones-Fourzán P, Candia-Zulbarán RI, Negrete-Soto F, BarradasOrtiz C, Huchin-Mian JP, Lozano-Álvarez E (2012) Influence of local habitat features on disease avoidance by Caribbean spiny lobsters in a casita-enhanced bay. Dis Aquat Org 100:135-148

Briones-Fourzán P, Muñoz de Cote-Hernández R, Lozano-Álvarez E (2016) Variability in prevalence of Cymatocarpus solearis (Trematoda, Brachycoeliidae) in Caribbean spiny lobsters Panulirus argus (Decapoda: Palinuridae) from Bahía de la Ascensión (Mexico). J Invertebr Pathol 137:62-70

Butler MJ, Behringer DC, Shields JD (2008) Transmission of Panulirus argus virus $1(\mathrm{PaV} 1)$ and its effect on the survival of juvenile Caribbean spiny lobster. Dis Aquat Org 79:173-182

Candia-Zulbarán RI, Briones-Fourzán P, Negrete-Soto F, Barradas-Ortiz C, Lozano-Álvarez E (2012) Variability in clinical prevalence of $\mathrm{PaV} 1$ in Caribbean spiny lobsters occupying commercial casitas over a large bay in Mexico. Dis Aquat Org 100:125-133

Carmona-Suárez C, Poupin J (2016) Majoidea crabs from Guadeloupe Island, with a documented list of species for the Lesser Antilles (Crustacea, Decapoda, Brachyura, Majoidea). Zoosystema 38:353-387

Chace FA Jr (1972) The shrimps of the Smithsonian-Bredin Caribbean expeditions with a summary of the West Indian shallowwater species (Crustacea: Decapoda: Natantia). Smithson Contrib Zool 98:1-179

Civitello DJ, Cohen J, Fatima H, Halstead NT, Liriano J, McMahon TA, Ortega CN, Sauer EL, Sehgal T, Young S, Rohr JR (2015) Biodiversity inhibits parasites: broad evidence for the dilution effect. Proc Natl Acad Sci USA 112:8667-8671

Clark A, Behringer D, Moss Small J, Waltzek T (2018) Partial validation of a TaqMan real-time quantitative PCR assay for the detection of Panulirus argus virus 1. Dis Aquat Organ 129:193-198

Clarke KR (1993) Non-parametric multivariate analyses of changes in community structure. Aust J Ecol 18:117-143

Clarke KR, Gorley RN (2015) PRIMER v7: user manual/tutorial. PRIMER E, Plymouth

Clarke KR, Warwick RM (2001) Change in marine communities: an approach to statistical analysis and interpretation, 2nd edn. PRIMER-E, Plymouth

Clarke KR, Somerfield PJ, Gorley RN (2008) Testing of null hypotheses in exploratory community analyses: similarity profiles and biota-environment linkage. J Exp Mar Biol Ecol 366:56-69
Cribb TH, Bray RA, Littlewood TJ (2001) The nature and evolution of the association among digeneans, molluscs and fishes. Int $\mathbf{J}$ Parasitol 31:997-1011

Cribb TH, Bray RA, Olson PD, Littlewood TJ (2003) Life cycle evolution in the Digenea: a new perspective from phylogeny. Adv Parasitol 54:197-254

Cruz-Quintana Y (2012) Epizootiología de los patógenos Panulirus argus Virus 1 (PaV1) y Cymatocarpus solearis (Trematoda) en poblaciones de langosta espinosa Panulirus argus del Golfo de Batabanó, Cuba. PhD Thesis, Centro de Investigación y de Estudios Avanzados del Instituto Politécnico Nacional, Mérida

Davies C, Vogan C, Rowley A (2015) Effect of the copepod parasite Nicothoë astaci on haemolymph chemistry of the European lobster Homarus gammarus. Dis Aquat Organ 113:169-175

de Grave S, Fransen CHJM (2011) Carideorum catalogus: the recent species of the dendrobranchiate, stenopodidean, procarididean and caridean shrimps (Crustacea: Decapoda). Zool Med Leiden 85(9): 195-589, figs 1-59

Diez García YL, Jover Capote A (2015) List of marine crabs (Decapoda: Anomura and Brachyura) of shallow littoral of Santiago de Cuba, Cuba. Check List 11:1601

Dunn OJ (1964) Multiple comparisons using rank sums. Technometrics 6:241-252

Eggleston DB, Lipcius RN (1992) Shelter selection by spiny lobster under variable predation risk, social conditions, and shelter size. Ecology 73:992-1011

Eggleston DB, Lipcius RN, Miller D, Cobá-Cetina L (1990) Shelter scaling regulates survival of Caribbean spiny lobster, Panulirus argus. Mar Ecol Prog Ser 62:70-88

Elzinga CL, Salzer DW, Willoughby JW (1998) Measuring and monitoring plant populations. Bureau of Land Management, Denver

Fields A, Moore E (1983) The larval biology of Brachidontes modiolus (Linné, 1767) (Bivalvia: Mytilidae). Veliger 26:52-61

Fisheries and aquaculture software. FishStatJ-software for fishery statistical time series. In: FAO Fisheries and Aquaculture Department [online]. Rome. Updated 21 July 2016. [Cited 27 January 2019]. http://www.fao.org/fishery/

García-Cubas A, Escobar F, Reguero M (1999) Gastrópodos marinos de la Península de Yucatán. Rev Soc Mex Hist Nat 49:127-146

Gómez del Prado MG, Álvarez-Cadena J, Lamothe-Argumedo R, Grano-Maldonado M (2003) Cymatocarpus solearis: a brachycoeliid metacercaria parasitizing Panulirus argus (Crustacea: Decapoda) from the Mexican Caribbean Sea. An Inst Biol Univ Nac Autón México Ser Zool 74:1-10

González-Gómez R, Briones-Fourzán P, Álvarez-Filip L, LozanoÁlvarez E (2018) Diversity and abundance of conspicuous macrocrustaceans on coral reefs differing in level of degradation. PeerJ 6:e4922

Grano-Maldonado M, Álvarez-Cadena JN (2010) In vitro cultivation of Cymatocarpus solearis (Brachycoeliidae) metacercariae to obtain the adult stage without the marine turtle definitive host. Korean J Parasitol 48:49-55

Gratwicke B, Speight MR (2005) The relationship between fish species richness, abundance and habitat complexity in a range of shallow tropical marine habitats. J Fish Biol 66:650-667

Hammer Ø, Harper DAT, Ryan PD (2001) PAST: paleontological Statistics software package for education and data analysis. Paleontol Electron 4(1):1-9

Harvell CD, Mitchell CE, Ward JR, Altizer S, Dobson AP, Ostfeld RS, Samuel MD (2002) Climate warming and disease risks for terrestrial and marine biota. Science 296:2158-2162

Harvell D, Aronson R, Baron N, Connell J, Dobson A, Ellner S, Gerber L, Kim K, Kuris A, McCallum H, Lafferty K, McKay B, Porter J, Pascual M, Smith G, Sutherland K, Ward J (2004) The rising tide of ocean diseases: unsolved problems and research priorities. Front Ecol Environ 2:375-382 
Hendler G, Miller JE, Pawson DL, Kier PM (1995) Sea stars, sea urchins, and allies: echinoderms of Florida and the Caribbean. Smithsonian Institution Press, Washington

Huchin-Mian JP, Rodríguez-Canul R, Briones-Fourzán P, LozanoÁlvarez E (2013) Panulirus argus virus 1 (PaV1) infection prevalence and risk factors in a Mexican lobster fishery employing casitas. Dis Aquat Org 107:87-97

Humman P (1994) Reef creature identification: Florida, Caribbean, Bahamas. New World Publications, Jacksonville

Johnson PTJ, Thieltges DW (2010) Diversity, decoys and the dilution effect: how ecological communities affect disease risk. J Exp Biol 213:961-970

Keesing F, Holt RD, Osfeld RS (2006) Effects of species diversity on disease risk. Ecol Lett 9:485-498

Lafferty KD, Gerber LR (2002) Good medicine for conservation biology: the intersection of epidemiology and conservation theory. Conserv Biol 16:593-604

Lafferty KD, Hofmann EE (2016) Marine disease impacts, diagnosis, forecasting, management and policy. Philos Trans R Soc London B Biol Sci 371:20150200

Laguarda-Figueras A, Hernández-Herrejón A, Solís-Marín FA, DuránGonzález A (2009) Los ofiuroideos del Caribe Mexicano y Golfo de México. CONABIO-UNAM, Ciudad de México

Lamb JB, Water JA, Bourne DG, Altier C, Hein MY, Fiorenza EA, Abu N, Jompa J, Harvell CD (2017) Seagrass ecosystems reduce exposure to bacterial pathogens of humans, fishes, and invertebrates. Science 355:731-733

Laracuente A, Brown RA, Jobin W (1979) Comparison of four species of snails as potential decoys to intercept schistosome miracidia. Am J Trop Med Hyg 28:99-105

Lassalle G, de Montaudouin X, Soudant P, Paillard C (2007) Parasite co-infection of two sympatric bivalves, the Manila clam (Ruditapes philippinarum) and the cockle (Cerastoderma edule) along a latitudinal gradient. Aquat Living Resour 20:33-42

Lessios HA (1996) Methods for quantifying abundance of marine organisms. In: Lang MA, Baldwin CC (eds) Methods and techniques of underwater research. American Academy of Underwater Sciences, Nahant, pp 149-157

Lozano-Álvarez E, Briones-Fourzán P, Phillips BF (1991) Fishery characteristics, growth, and movements of the spiny lobster Рanulirus argus in Bahía de la Ascensión, Mexico. Fish Bull 89:79-89

Lozano-Álvarez E, Luviano-Aparicio N, Negrete-Soto F, BarradasOrtiz C, Aguíñiga-García S, Morillo-Velarde PS, Álvarez-Filip L, Briones-Fourzán P (2017) Does reef architectural complexity influence resource availability for a large reef-dwelling invertebrate? J Sea Res 128:84-91

McCallum H, Gerber L, Jani A (2005) Does infectious disease influence the efficacy of marine protected areas? A theoretical framework. J Appl Ecol 42:688-698

McLaughlin PA, Komai T, Lemaitre R, Rahayu DL (2010) Annotated checklist of anomuran decapod crustaceans of the world (exclusive of the Kiwaoidea and families Chirostylidae and Galatheidae of the Galatheoidea): part I-Lithodoidea, Lomisoidea and Paguroidea. Raffles Bull Zool 23:5-107

McNulty J, Wark R, Moore H (1962) Level sea-bottom communities in Biscayne Bay and neighbouring areas. Bull Mar Sci Gulf Carib 12:204-233

Medina M, Baqueiro E, Aldana-Aranda D (2006) Guía ilustrada de conchas y caracoles de la Península de Yucatán. CYTED, Programa Iberoamericano de Ciencia y Tecnología para el Desarrollo, Mérida

Medina-Gómez I, Kjerfve B, Mariño I, Herrera-Silveira J (2014) Sources of salinity variation in a coastal lagoon in a karst landscape. Estuar Coasts 37:1329-1342
Montgomery-Fullerton MM, Cooper RA, Kauffman KM, Shields JD, Ratzlaff RE (2007) Detection of Panulirus argus Virus 1 in Caribbean spiny lobsters. Dis Aquat Org 76:1-6

Morris EK, Caruso T, Buscot F, Fischer M, Hancock C, Maier TS, Meiners T, Müller C, Obermaier E, Prati D, Socher SA, Sonnemann I, Wäschke N, Wubet T, Wurst S, Rillig MC (2014) Choosing and using diversity indices: insights for ecological applications from the German Biodiversity Exploratories. Ecol Evol 4:3514-3524

Morton JP (2018) Infection by Parorchis acanthus (Trematoda) decreases grazing by the keystone gastropod, Littoraria irrorata. PeerJ 6:e4544

Moss J, Behringer D, Shields JD, Baeza A, Aguilar-Perera A, Bush PG, Dromer C, Herrera-Moreno A, Gittens L, Matthews TR, McCord MR, Schärer MT, Reynal L, Truelove N, Butler MJ (2013) Distribution, prevalence, and genetic analysis of Panulirus argus virus 1 (PaV1) from the Caribbean Sea. Dis Aquat Org 104:129-140

Newcombe RG (1998) Two-sided confidence intervals for the single proportion: comparison of seven methods. Stat Med 17:857-872

Ng PKL, Guinot D, Davie PJF (2008) Systema Brachyurorum: part I. An annotated checklist of extant brachyuran crabs of the world. Raffles Bull Zool 17:1-286

Orlofske SA, Jadin RC, Preston DL, Johnson PTJ (2012) Parasite transmission in complex communities: predators and alternative hosts alter pathogenic infections in amphibians. Ecology 93:1247-1253

Peterson CH, Luettich RA Jr, Micheli F, Skilleter GA (2004) Attenuation of water flow inside seagrass canopies of differing structure. Mar Ecol Prog Ser 268:81-92

Quinn GP, Keough MJ (2002) Experimental design and data analysis for biologists. Cambridge Univ Press, Cambridge

Rutherford A (2001) Introducing ANOVA and ANCOVA: a GLM approach. SAGE Publications, London

Scoffin TP (1970) The trapping and binding of subtidal carbonate sediments by marine vegetation in Bimini Lagoon, Bahamas. J Sediment Petrol 40:249-273

Shields JD (2011) Diseases of spiny lobsters: a review. J Invertebr Pathol 106:79-91

Shields JD, Behringer DC (2004) A new pathogenic virus in the Caribbean spiny lobster Panulirus argus from the Florida Keys. Dis Aquat Org 59:109-118

Small HJ, Pagenkopp KM (2011) Reservoirs and alternate hosts for pathogens of commercially important crustaceans: a review. J Invertebr Pathol 106:153-164

Stanley SM (1970) Relation of shell form to life habits of the Bivalvia (Mollusca). Geol Soc Am Mem 125:1-296

Stewart JE (1984) Lobster diseases. Helgoländer Meeresunters $37: 243-254$

Taberlet P, Bonin A, Zinger L, Coissac E (2018) Environmental DNA: for biodiversity research and monitoring. Oxford University Press, Oxford

Théron A (2014) Chronobiology of trematode cercarial emergence: from data recovery to epidemiological, ecological and evolutionary implications. Adv Parasitol 88:123-164

Thieltges DW, Bordalo MD, Caballero-Hernández A, Prinz K, Jensen KT (2008) Ambient fauna impairs parasite transmission in a marine parasite-host system. Parasitology 135:1111-1116

Thieltges DW, Fredensborg BL, Studer A, Poulin R (2009) Large-scale patterns in trematode richness and infection levels in marine crustacean hosts. Mar Ecol Prog Ser 389:139-147

Wagner HP (1990) The genera Mithrax Latreille, 1818 and Mithraculus White, 1847 (Crustacea: Brachyura: Majidae) in the Western Atlantic Ocean. Zool Verhandel 264:3-65

Ward JR, Lafferty KD (2004) The elusive baseline of marine disease: are diseases in ocean ecosystems increasing? PLoS Biol 2(4):e120 
Warton DI, Hui FKC (2011) The arcsine is asinine: the analysis of proportions in ecology. Ecology 92:3-10

Williams AB (1984) Shrimps, lobsters and crabs of the Atlantic coast of the Eastern United States, Maine to Florida. Smithson Inst Press, Washington
Publisher's Note Springer Nature remains neutral with regard to jurisdictional claims in published maps and institutional affiliations. 